Supporting Information for

\title{
Supramicellar Nanofibrils with End-to-End Coupled Uniform Cylindrical Micelle Subunits via One-Step Assembly from A Liquid Crystalline Block Copolymer
}

\author{
Mingyan Luo, ${ }^{1}$ Bixin Jin, ${ }^{1}$ Yunjun Luo, ${ }^{1,2}$ Xiaoyu Li ${ }^{* 1,2,3}$
}

Table of Contents

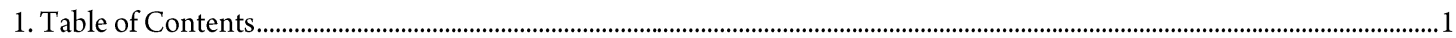

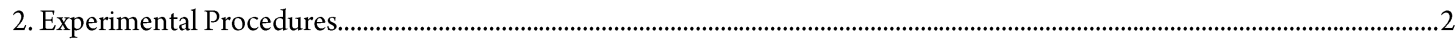

3. Materials and Equipment

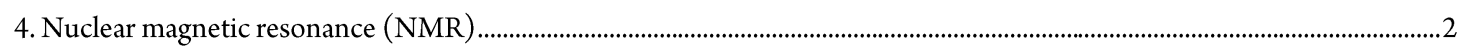

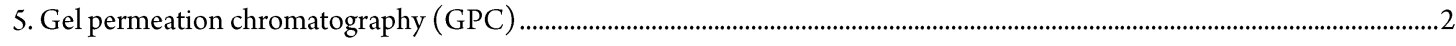

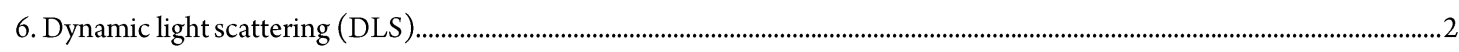

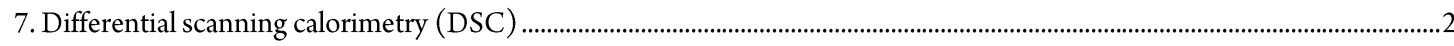

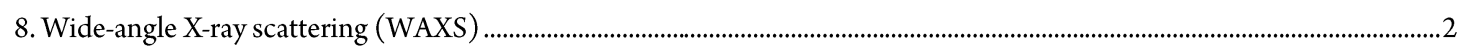

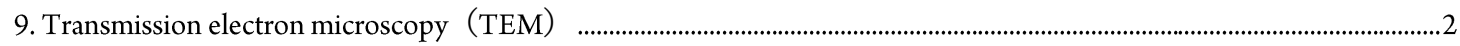

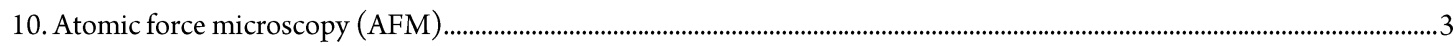

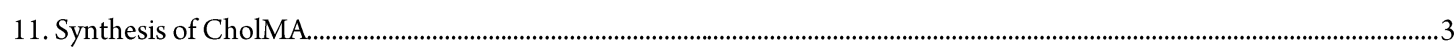

12. Synthesis of $\mathrm{P} t \mathrm{BA}-\mathrm{Br}$.................................................................................................................................................

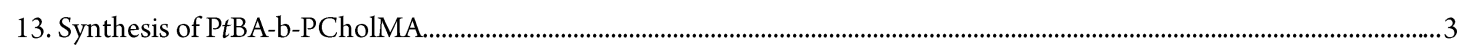

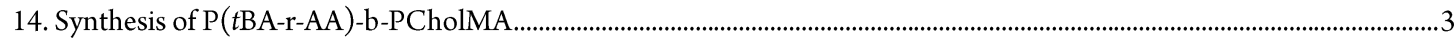

15. Synthesis of $\mathrm{P}(\mathrm{tBA}-\mathrm{r}-\mathrm{AA}-\mathrm{Fc})-\mathrm{b}-\mathrm{PCh}$

16. Preparation of hierarchical supramicellar nanofibrils...............................................................................................................

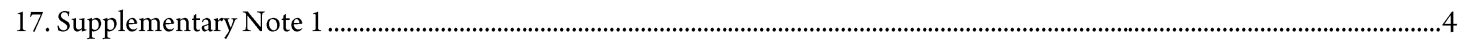

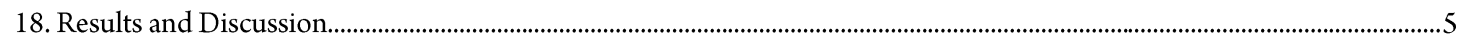

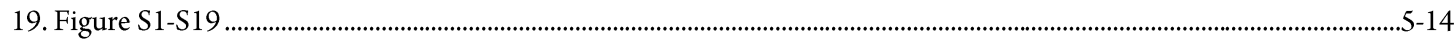

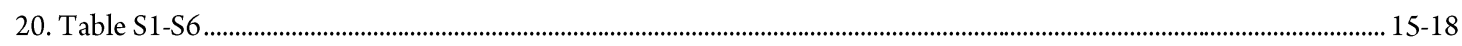

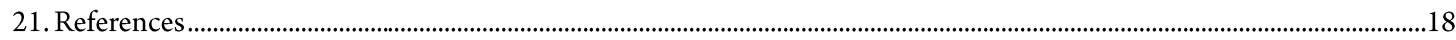




\section{Experimental Procedures}

\section{Materials and Equipment.}

tert-Butyl acrylate $(t \mathrm{BA})$, dichloromethane, tetrahydrofuran $(\mathrm{THF})$ and toluene were distilled over $\mathrm{CaH}_{2}$ before use. All other solvents were used as received without further purification. The initiator ethyl 2-bromoisobutyrate (99\%, EBiB), (3dimethylaminopropyl)ethyl-carbodiimid monohydrochloride (EDCI), 4-dimethylaminopyridine (DMAP), 1(ferrocenyl)ethanol, $N, N, N^{\prime}, N^{\prime}, N^{\prime \prime}$-pentamethyldiethyl enetriamine (99\%, PMDETA), cholesteryl chloroformate (99\%), and 2-hydroxyethyl methacrylate (99\%) were purchased from Aldrich and used as received unless otherwise stated. The LC monomer, cholesteryl methacryloyoxy ethyl carbonate (CholMA), was synthesized from cholesteryl chloroformate ( $99 \%$, Aldrich) and 2-hydroxyethyl methacrylate (99\%, Aldrich) as described previously. ${ }^{1}$ All of the self-assembly experiments were performed with HPLC grade solvents that were acquired from Fisher.

\section{Nuclear magnetic resonance (NMR)}

${ }^{1} \mathrm{H}$ NMR spectra were recorded using Avance 500 (Bruker A.G.) instrument (operating at $500 \mathrm{MHz}$ ) at $25^{\circ} \mathrm{C}$.

\section{Gel permeation chromatography (GPC)}

Molecular weights and polydispersity indices $\left(M_{\mathrm{w}} / M_{\mathrm{n}}\right)$ of polymers were obtained by gel permeation chromatography (GPC) using a Viscotex GPC max Chromatograph equipped with styrene/divinylbenzene columns with pore sizes of $500 \AA$ and $100000 \AA$, VE 3580 refractometer. Butylated hydroxytoluene (0.025\%, w.t.) stabilized THF was used as the eluent, with a flow rate of $1.0 \mathrm{~mL} / \mathrm{min}$. Samples were dissolved in the eluent $(10 \mathrm{mg} / \mathrm{mL}$ ) and filtered (Acrodisc, PTFE membrane, 0.45 $\mu \mathrm{m})$ before injection. The calibration of refractive index detector was carried out using polystyrene standards (Viscotek).

\section{Dynamic light scattering (DLS)}

DLS experiments were performed using a nano series Malvern Zetasizer instrument equipped with a $633 \mathrm{~nm}$ laser. Samples were analyzed in $1 \mathrm{~cm}$ glass cuvettes at the condition of $110^{\circ} \mathrm{C} \sim 25^{\circ} \mathrm{C}$ with a scattering angle of $173^{\circ}$. The refractive index of the block copolymers involved was assumed to be the same as polystyrene at different temperatures. The results of DLS studies were reported as the apparent hydrodynamic diameter $\left(D_{\mathrm{h}}\right)$, acknowledging that the particles have been modelled as hard spheres in the experiments.

\section{Differential scanning calorimetry (DSC)}

Differential scanning calorimetry (DSC) were performed on a TA Instruments Q100 calorimeter at a scan rate of $3{ }^{\circ} \mathrm{C} / \mathrm{min}$ under nitrogen $(50 \mathrm{~mL} / \mathrm{min})$.

\section{Small-angle X-ray scattering (SAXS)}

Powder small-angle X-ray scattering (SAXS) analysis was performed at $25^{\circ} \mathrm{C}$ using a Brucker D8 Advanced X-ray diffraction measurement system operated at $40 \mathrm{kV}$ and $40 \mathrm{~mA}$ with $\mathrm{Cu} \mathrm{Ka}$ radiation $(\lambda=0.154 \mathrm{~nm})$. The data were collected at a scan rate of $0.1^{\circ} \mathrm{s}^{-1}$.

\section{Transmission electron microscopy (TEM)}

The samples for transmission electron microscopy (TEM) were prepared by drop-casting (ca. $5 \mu \mathrm{L}$ ) the micellar solution onto a carbon coated copper grid, which was placed on a piece of filter paper to remove excess solvent. Bright-field TEM micrographs were obtained on a JEOL1200EX II microscope operating at $80 \mathrm{kV}$ equipped with an SIS MegaViewIII digital camera. No staining was applied for TEM samples. Images were analyzed using the ImageJ software package developed at the US National Institute of Health. For the statistical dimension analysis, over 300 micelles were carefully traced manually to determine the diameter. 
Micelle length distributions were obtained by analyzing the length data. The number average micelle length $\left(L_{\mathrm{n}}\right)$ and weight average micelle length $\left(L_{\mathrm{w}}\right)$ were calculated using eq. S1 and S2 from measurements of the contour lengths $\left(L_{\mathrm{i}}\right)$ of individual micelles, where $N_{\mathrm{i}}$ is the number of micelles of length $L_{\mathrm{i}}$, and $n$ is the number of micelles examined in each sample.

$$
\begin{aligned}
& L_{\mathrm{n}}=\frac{\sum_{i=1}^{n} N_{i} L_{i}}{\sum_{i=1}^{n} N_{i}} \\
& L_{\mathrm{w}}=\frac{\sum_{i=1}^{n} N_{i} L_{i}{ }^{2}}{\sum_{i=1}^{n} N_{i} L_{i}}
\end{aligned}
$$

The distribution of micelle lengths is characterized by both $L_{\mathrm{w}} / L_{\mathrm{n}}$ and the standard deviation of the length distribution $\sigma$.

\section{Atomic force microscopy (AFM)}

AFM experiments were conducted directly on the carbon-coated copper grid used for TEM analysis. AFM images were recorded with a Cypher ES (Asylum Research, CA, USA). The images of the samples were acquired in tapping mode in ambient environment.

\section{Synthesis of CholMA}

In a typical reaction, to a solution of 2-hydroxyethyl methacrylate $(3.9 \mathrm{~g}, 30 \mathrm{mmol})$ and pyridine $(1.75 \mathrm{~g}, 22 \mathrm{mmol})$ in $\mathrm{CH}_{2} \mathrm{Cl}_{2}$ $(20 \mathrm{~mL})$ was added dropwise a solution of cholesteryl chloroformate $(9 \mathrm{~g}, 20 \mathrm{mmol})$ in $\mathrm{CH}_{2} \mathrm{Cl}_{2}(20 \mathrm{~mL})$ at $0^{\circ} \mathrm{C}$. The mixture was allowed to warm to room temperature and stirred for $6 \mathrm{~h}$. The mixture was diluted with $\mathrm{CH}_{2} \mathrm{Cl}_{2}(125 \mathrm{~mL})$, washed with $1 \mathrm{~N} \mathrm{HCl}(30 \mathrm{~mL})$, washed with water, and dried over anhydrous $\mathrm{MgSO}_{4}$. After solvent removal, the crude product was purified by column chromatography (silica gel, $\mathrm{CH}_{2} \mathrm{Cl}_{2} /$ Hexane $3: 1$ ) to yield $8.4 \mathrm{~g}$ of the product (yield $77 \%$ ).

\section{Synthesis of PtBA-Br}

$\mathrm{CuBr}(5.8 \mathrm{mg}, 0.04 \mathrm{mmol})$, PMDETA $(7 \mathrm{mg}, 0.04 \mathrm{mmol}), t \mathrm{BA}(1.24 \mathrm{mg}, 8 \mathrm{mmol}), \mathrm{EBiB}(7.8 \mathrm{mg}, 0.04 \mathrm{mmol})$ and $2 \mathrm{~mL}$ toluene were introduced into a Schlenk tube and degassed with three freeze-pump-thaw cycles. Subsequently, the polymerization solution was heated at $60^{\circ} \mathrm{C}$ for $5 \mathrm{~h}$ under a nitrogen atmosphere with vigorous stirring. The polymer was purified with $\mathrm{Al}_{2} \mathrm{O}_{3}$ column chromatography and by repeated precipitations from THF into a mixture of water and methanol, and dried under reduced pressure. A colorless solid was obtained as the final product ( $460 \mathrm{mg}$, yield $42 \%$ ).

\section{Synthesis of PtBA-b-PCholMA}

Macroinitiator PtBA (145 mg, $0.01 \mathrm{mmol}), \mathrm{CuBr}$ (3 mg, $0.02 \mathrm{mmol})$, PMDETA ( $3.5 \mathrm{mg}, 0.02 \mathrm{mmol})$, CholMA (792 mg, $1.5 \mathrm{mmol}$ ) and $1.5 \mathrm{~mL}$ toluene were introduced into a Schlenk tube and degassed with three freeze-pump-thaw cycles. Subsequently, the polymerization solution was heated at $80^{\circ} \mathrm{C}$ for $4 \mathrm{~h}$ under a nitrogen atmosphere with vigorous stirring. The polymer was purified with $\mathrm{Al}_{2} \mathrm{O}_{3}$ column chromatography and by repeated precipitations from THF into methanol and then dried under reduced pressure. A colorless solid was obtained as the final product ( $421 \mathrm{mg}$, yield $50 \%$ ).

\section{Synthesis of P(tBA-r-AA)-b-PCholMA}

In a typical experiment, partial hydrolysis of PtBA- $b$-PCholMA was achieved in $\mathrm{CH}_{2} \mathrm{Cl}_{2} /$ TFA at $\mathrm{v} / \mathrm{v}=95 / 5$ using triethylsilane as the cation scavenger and by controlling the hydrolysis time ( 5 minutes) at $25^{\circ} \mathrm{C}$. The intense characteristic peak at $\delta=1.45 \mathrm{ppm}$, corresponding to the methyl protons of the tert-butyl group. It suggested that the hydrolysis rate of PtBA blocks hydrolyzed into PAA was 7 \% (Supplementary Fig.13).

\section{Synthesis of P(tBA-r-AA-Fc)-b-PCholMA}

To label the ferrocene moieties, 1-(ferrocenyl)ethanol $(0.01 \mathrm{mmol}, 2.3 \mathrm{mg})$, EDCI $(0.01 \mathrm{mmol}, 1.92 \mathrm{mg})$, DMAP (0.01 mmol, $1.22 \mathrm{mg}$ ), $\mathrm{P}\left(\mathrm{tBA}-\mathrm{r}\right.$-AA)- $b$-PCholMA ( $5 \mathrm{mg}$ ) were dissolved in $2 \mathrm{~mL} \mathrm{CH}_{2} \mathrm{Cl}_{2}$,and reacted overnight. The product repeated precipitations into methanol and then dried at reduced pressure. The intense characteristic peak at $\delta=4.5-4.0 \mathrm{ppm}$, 
corresponding to the protons of the dicyclopentadiene group (Supplementary Fig.18).

Preparation of hierarchical supramicellar nanofibrils

The hierarchical supramicellar nanofibrils were obtained by directly dispersing the diblock copolymer solid into the mixtures of NMP and $i-\mathrm{BuOH}$. The solutions were heated at $110^{\circ} \mathrm{C}$ for $1 \mathrm{~h}$ before the solution was allowed to cool down naturally to room temperature $\left(21^{\circ} \mathrm{C}\right)$ in $3 \mathrm{~h}$.

\section{Supplementary Note 1}

\section{Persistence length calculation methods. ${ }^{2}$}

The estimation was carried out using FibreApp tracking and the analysis software from literature. ${ }^{2}$ For the stiffness analysis, the blue traces were used, which were the rods tracked with the software in the image, as shown in Fig.S11. Meansquared end-to-end distance (MSED) for a worm-like chain (WLC) model was dependent on the internal contour length $L$ in two dimensions, which was calculated using eq. S3

$$
<\mathrm{R}>^{2}=4 \lambda\left[1-2 \lambda\left(1-\mathrm{e}^{-\frac{1}{2 \lambda}}\right)\right]
$$

where $\lambda$ is the persistence length, and $R$ is the direct distance between any pair of segments along a contour separated by arc length $l$. In Fig.S1 1 , the persistence length was estimated to be $6.2 \pm 0.07 \mu \mathrm{m}$. End-to-end distance method showed good fitting results for all fibrils. 


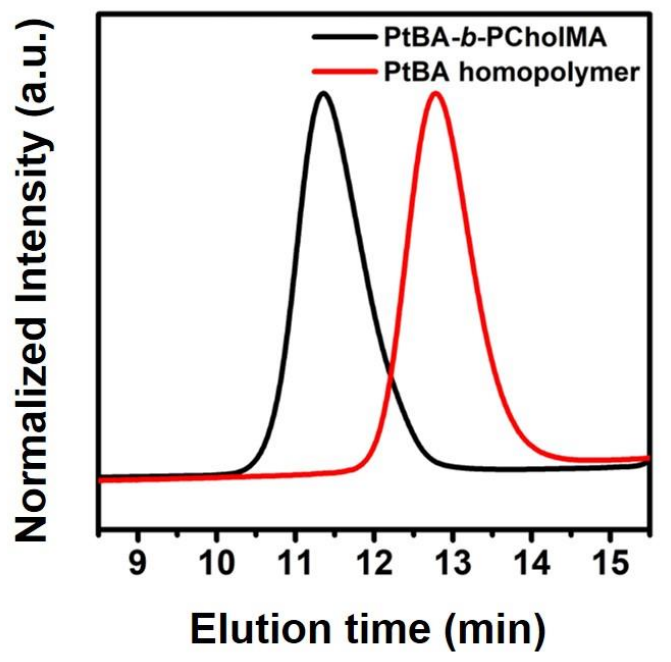

Figure S1 Normalized GPC refractive index (RI) traces of the PtBA homopolymer (red) and $\mathrm{P}_{\mathrm{B}} \mathrm{BA} \mathrm{A}_{113}-b$-PCholMA $\mathrm{A}_{86}$ diblock copolymer (black).

(a)

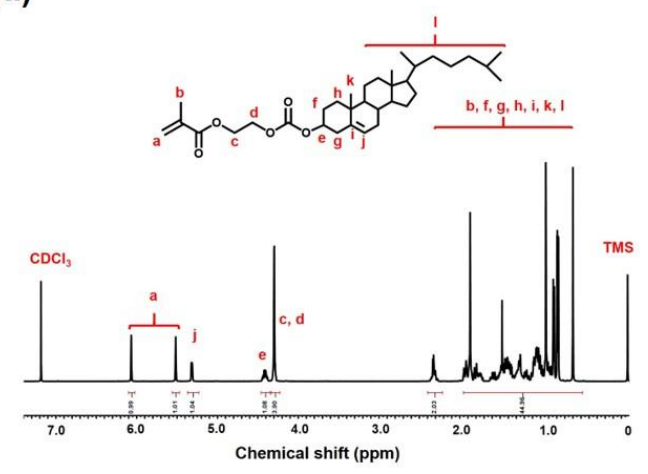

(b)

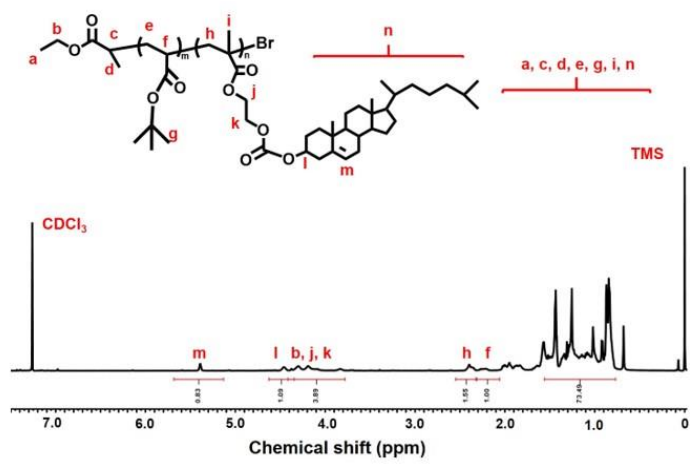

Figure S2 ${ }^{1} \mathrm{H}$ NMR spectrum of (a) CholMA, (b) the $\mathrm{P}^{\mathrm{B} A} \mathrm{~A}_{113}-\mathrm{b}$-PCholMA 86 diblock copolymer. $\mathrm{CDCl}_{3}$ was used as the solvent. 


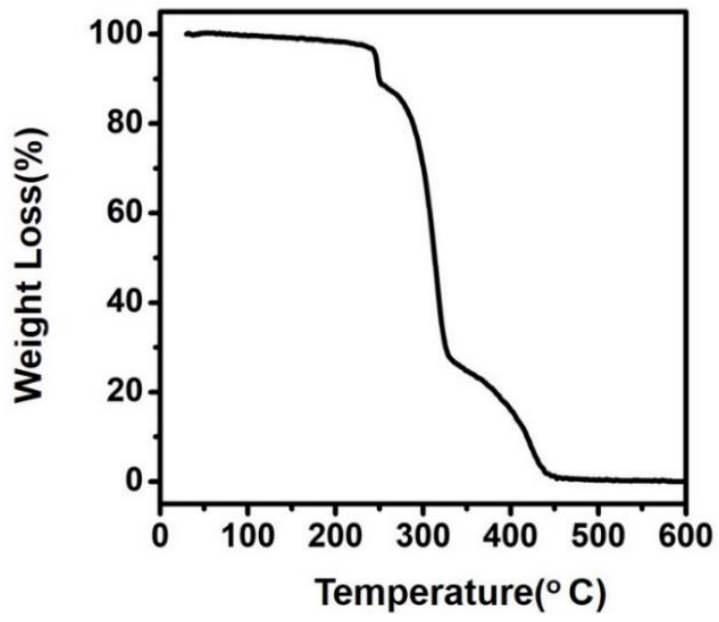

Figure S3 TGA trace of the $\mathrm{P}_{\mathrm{B}} \mathrm{B}_{113}-b$-PCholMA ${ }_{86}$ diblock copolymer.
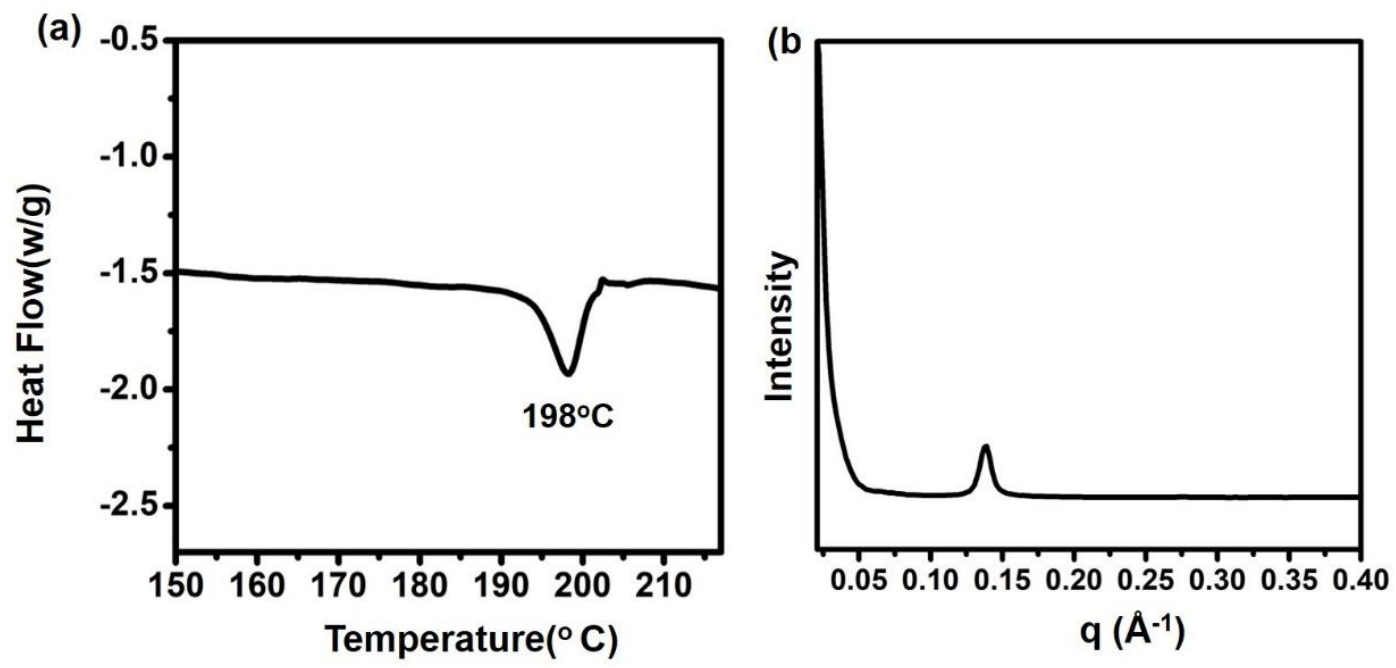

Figure S4 (a) DSC trace, (b) SAXS curve of the bulk PtBA ${ }_{113}-b$-PCholMA $A_{86}$ diblock copolymer.

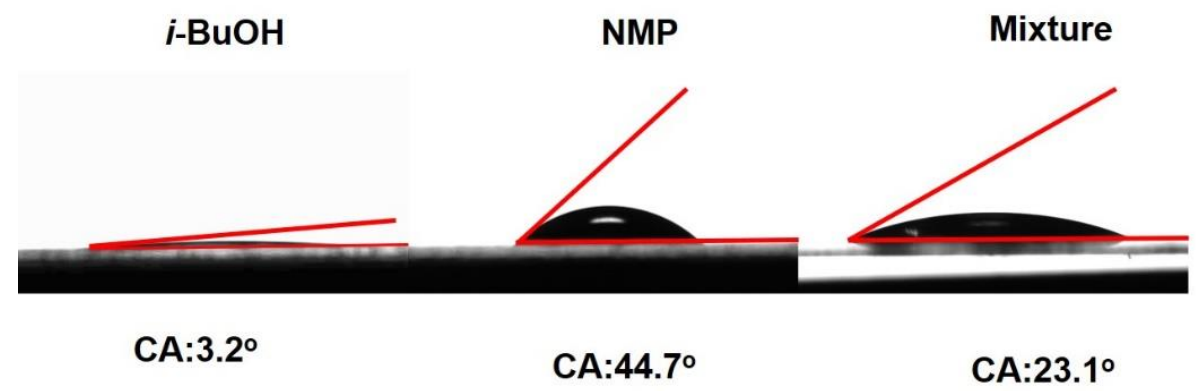

Figure S5 Contact angle images for droplets $i-\mathrm{BuOH}, \mathrm{NMP}$ and mixture $\left(\mathrm{V}_{i-\mathrm{BuOH}}=70 \%\right)$ on PCholMA films. 


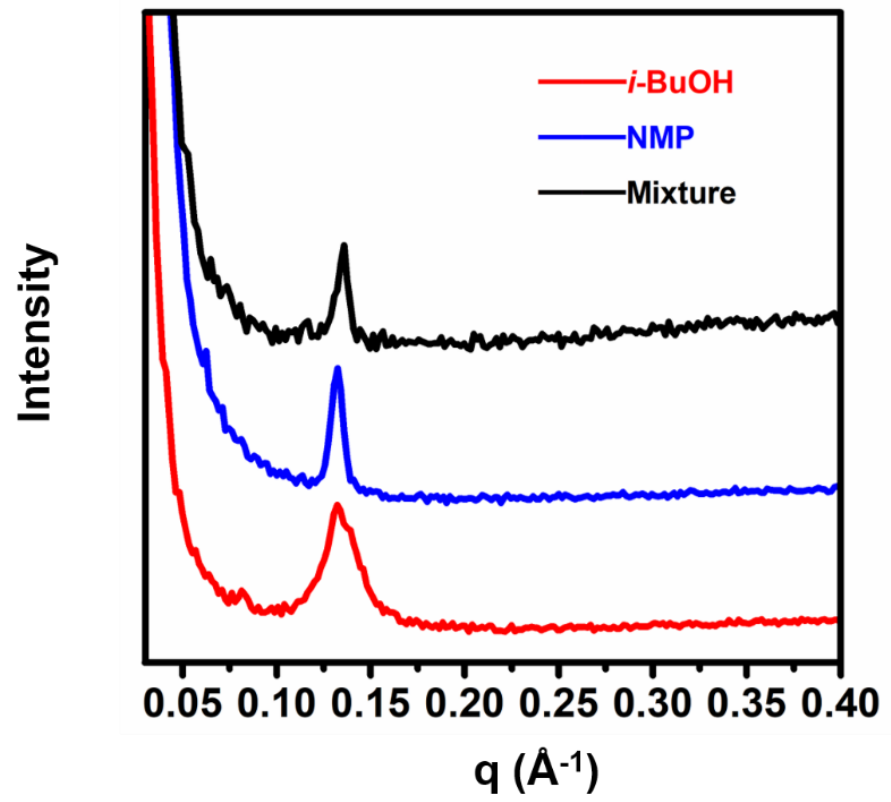

Figure S6 Plot of the scattering intensity along equator versus the scattering vector $q$ of dried micelles (obtained by volatilizing the micelle solutions). The diffraction signals at $0.14 \AA$ at small angles correspond to $4.4 \mathrm{~nm}$, the interlayer distance between the lamellar layers.
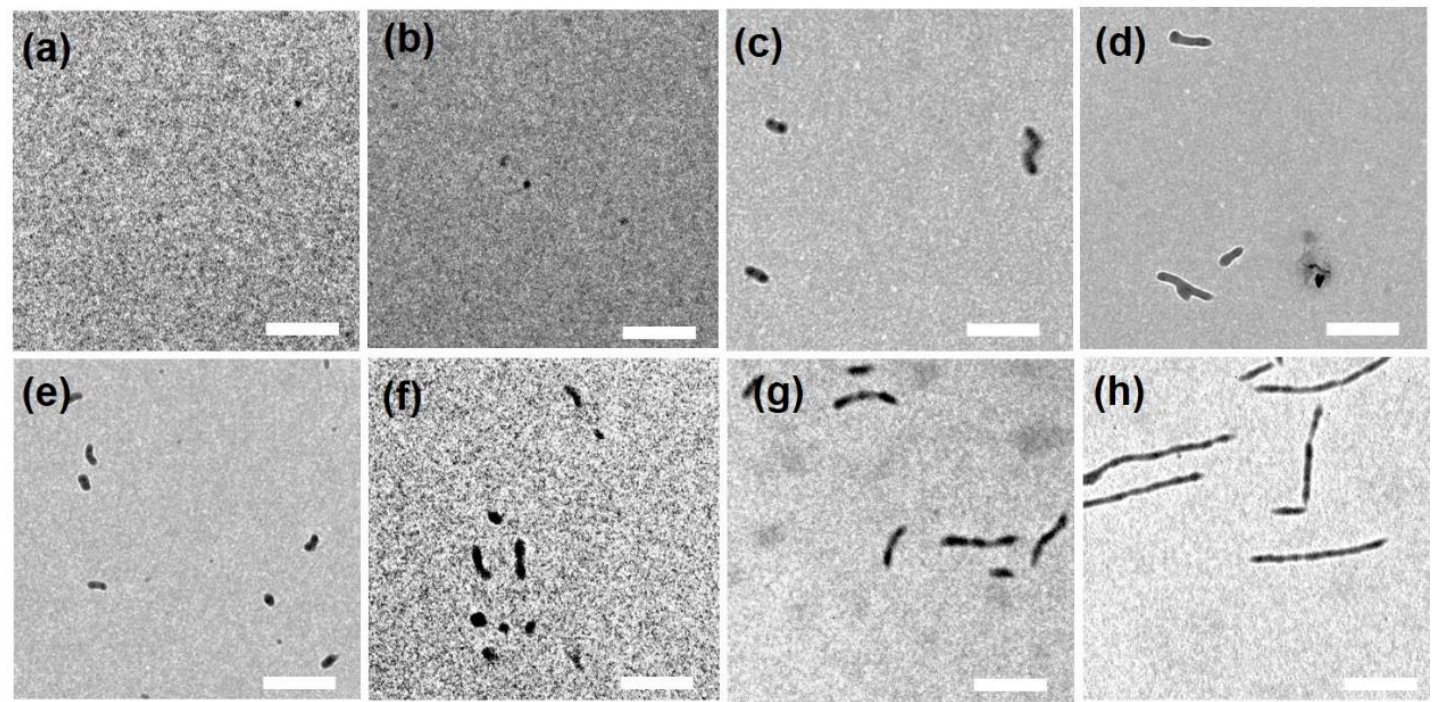

Figure S7 TEM images of the cylindrical micelles. The $i-\mathrm{BuOH}(\mathrm{a}-\mathrm{d})$, and NMP (e-h) solutions of the sample $(0.1 \mathrm{mg} / \mathrm{mL})$ was heated at $110^{\circ} \mathrm{C}$ for $60 \mathrm{~min}(\mathrm{a}, \mathrm{e})$, and naturally cooled to $(\mathrm{b}, \mathrm{f}) 80^{\circ} \mathrm{C},(\mathrm{c}, \mathrm{g}) 50^{\circ} \mathrm{C}$, and $(\mathrm{d}, \mathrm{h}) 30^{\circ} \mathrm{C}$. Scale bars are 500 nm. 

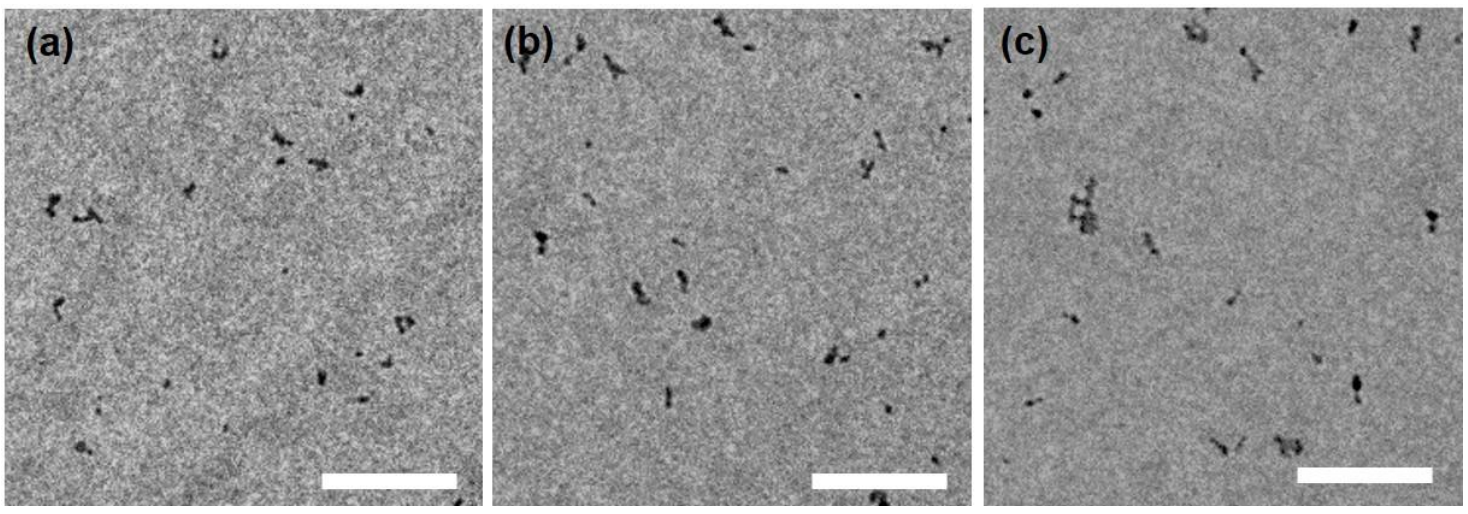

Figure S8 TEM images of the sample in $i-\mathrm{BuOH}$ and NMP mixture solution $\left(V_{i-\mathrm{BuOH}}=70 \%\right)$ heated at $110^{\circ} \mathrm{C}$ for $60 \mathrm{~min}$ and naturally cooled to (a) $110^{\circ} \mathrm{C}$, (b) $90^{\circ} \mathrm{C}$, (c) $80^{\circ} \mathrm{C}$. The solution concentration was $0.1 \mathrm{mg} / \mathrm{mL}$. Scale bars are $1 \mu \mathrm{m}$.

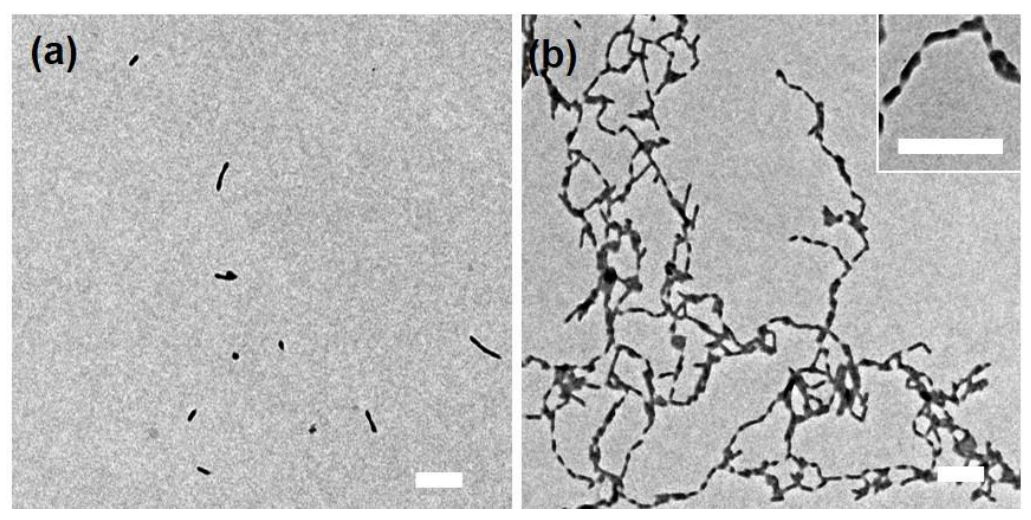

Figure S9 TEM images of (a) cylindrical micelles formed by directly heating in pure $i-\mathrm{BuOH}$ at $110^{\circ} \mathrm{C}$ for $60 \mathrm{~min}$ and naturally cooled to r.t. within $3 \mathrm{~h}$, and (b) the structures obtained 1 day after adding equal amount of NMP to the $i$-BuOH solution at r.t.. Scale bars are $500 \mathrm{~nm}$ and these in insets are $500 \mathrm{~nm}$.
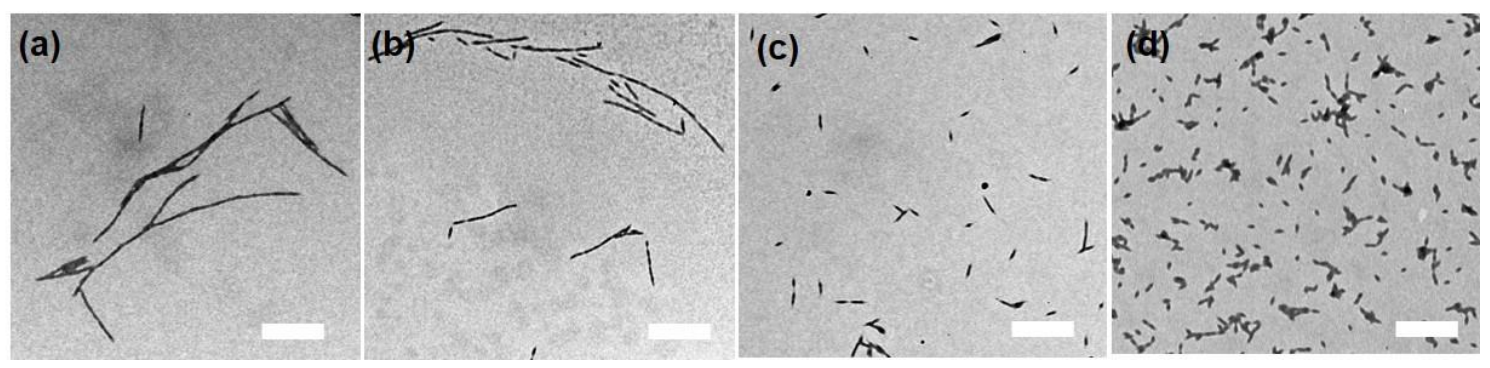

Figure S10 TEM images of ill-defined micelles in the solvent mixture of $i-\mathrm{BuOH}$ and NMP with $V_{i-\mathrm{BuOH}}$ of (a) $10 \%$, (b) $20 \%$, (c) $80 \%$, and (d) $90 \%$. The sample solutions $(0.1 \mathrm{mg} / \mathrm{mL})$ were heated at $110{ }^{\circ} \mathrm{C}$ for $60 \mathrm{~min}$ and naturally cooled to r.t. within $3 \mathrm{~h}$.The Scale bars are $1 \mu \mathrm{m}$. 

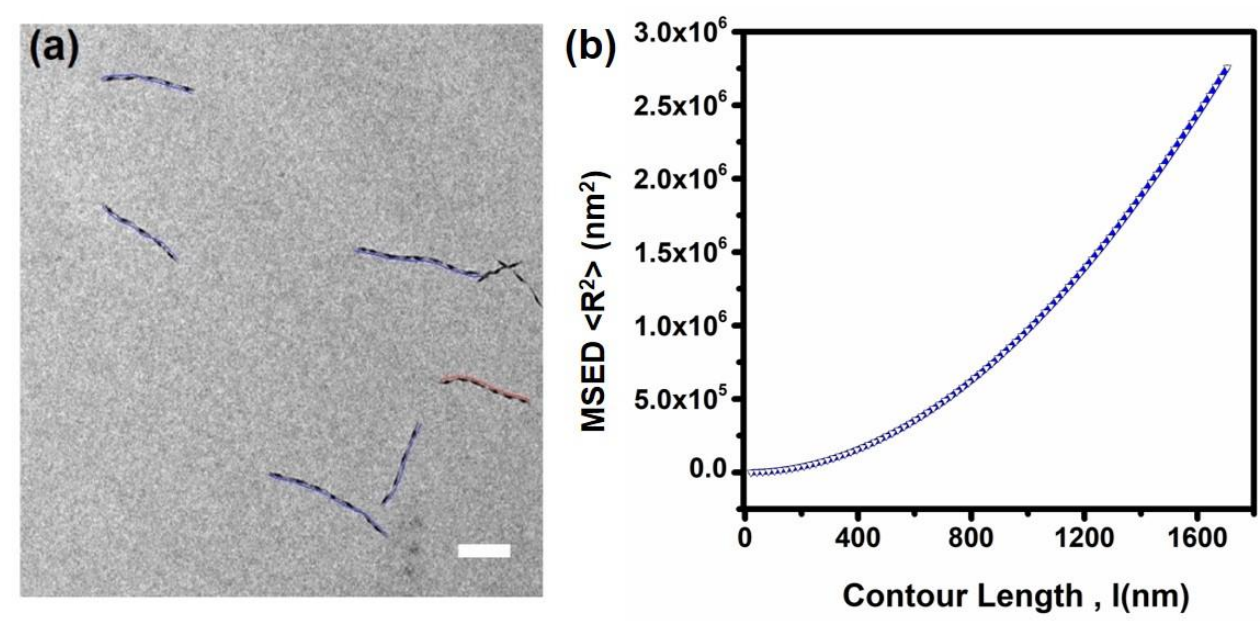

Figure S1 1 (a) Software tracking image of the TEM image of the supramicellar fibrils ( $70 \% i$-BuOH, $0.1 \mathrm{mg} / \mathrm{mL}$ ). (b) Plot of calculated MSED between contour segments along the tracked fibrils, and the corresponding MSED fit (red curve) between contour segments. Scale bar is $1 \mu \mathrm{m}$.
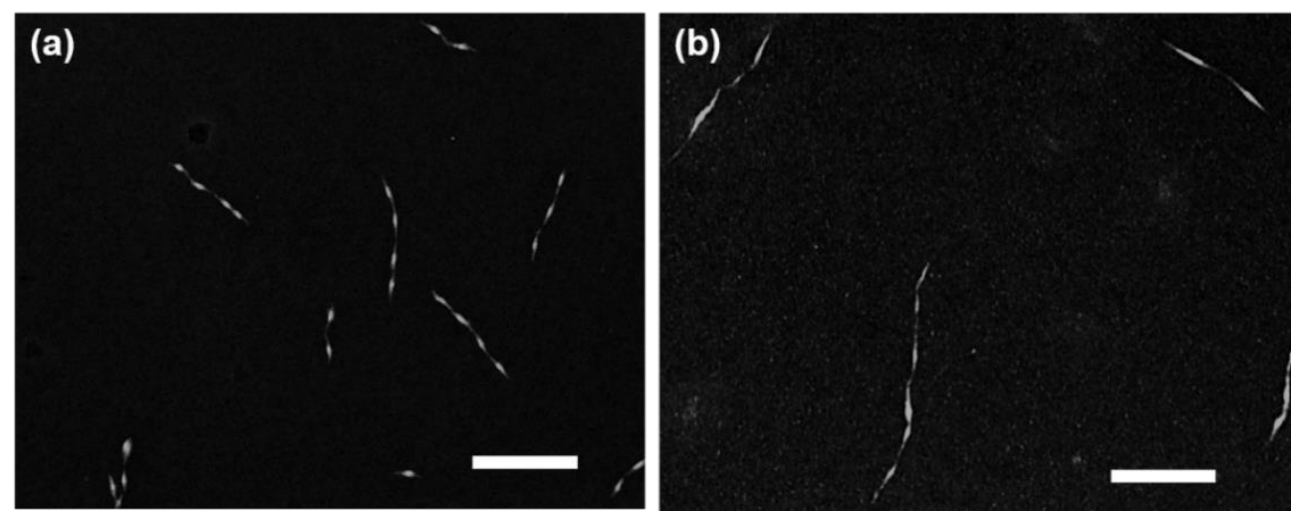

Figure S12 Dark-field TEM images of the supramicellar fibrils obtained under conditions of (a) $V_{i \text {-BuOH }}=70 \%, c=0.1$ $\mathrm{mg} / \mathrm{mL}$; (b) $V_{i-\mathrm{BuOH}}=70 \%, c=0.01 \mathrm{mg} / \mathrm{mL}$. Scale bars are $1 \mu \mathrm{m}$. 


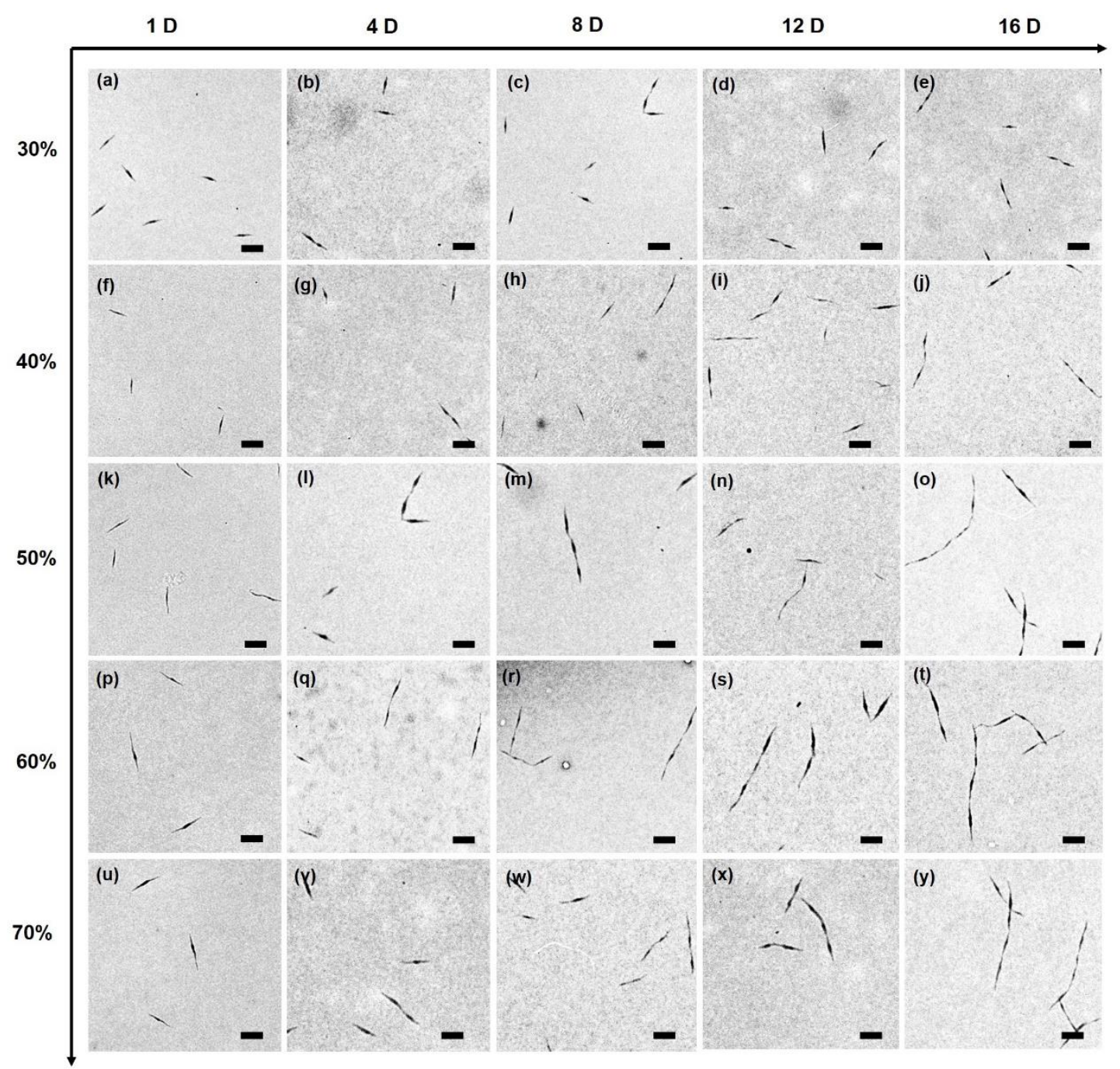

Figure S13 TEM images of the supramiceller fibrils produced with different $V_{i \text {-BuOH }} \%$ and incubation time, with $c=0.01$ $\mathrm{mg} / \mathrm{mL}$. Scale bars are $500 \mathrm{~nm}$. 


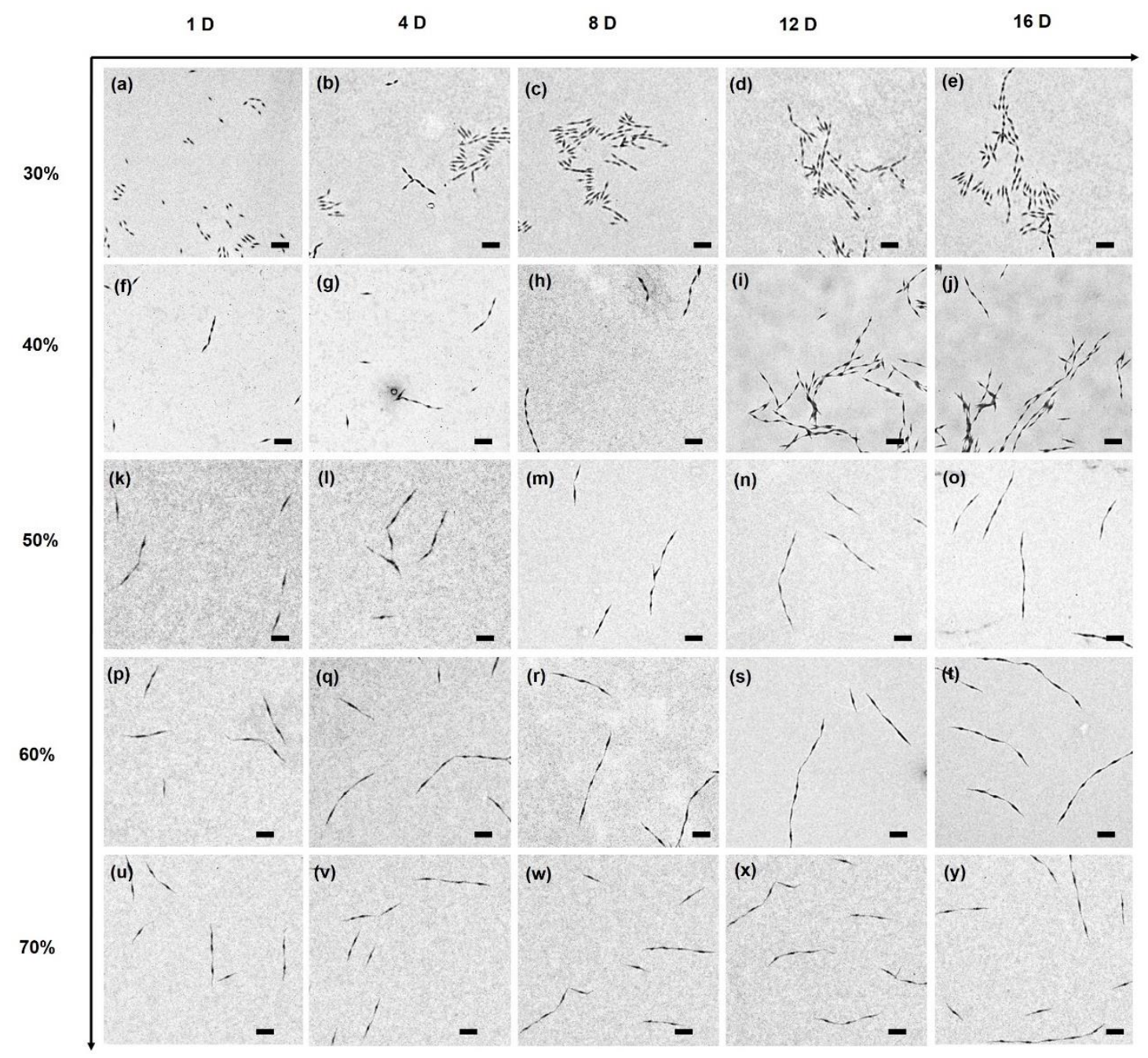

Figure S14 TEM images of the supramiceller fibrils produced with different $V_{i \text {-BuOH }} \%$ and incubation time, with $c=0.05$ $\mathrm{mg} / \mathrm{mL}$. Scale bars are $500 \mathrm{~nm}$. 


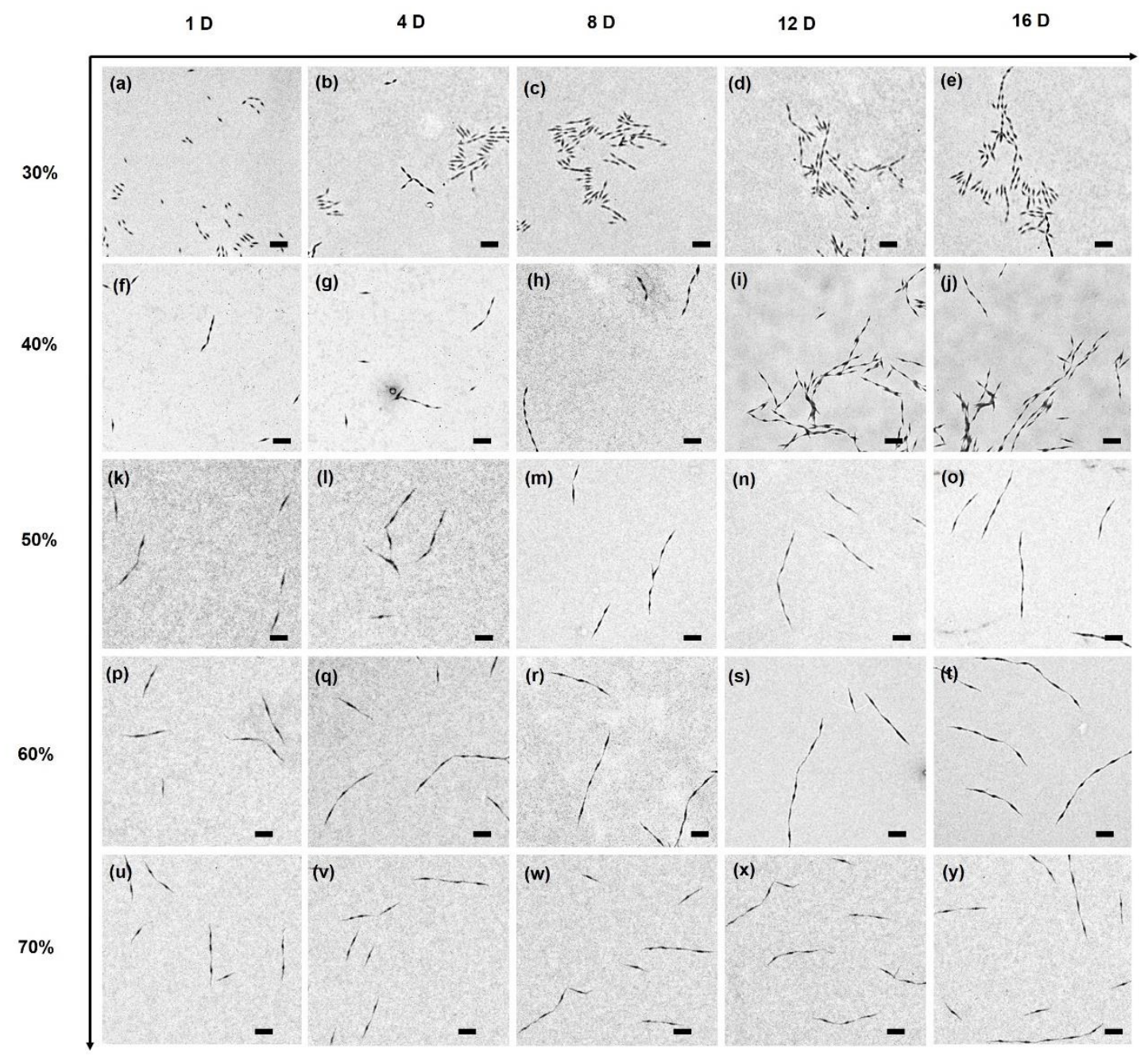

Figure S15 TEM images of the supramiceller fibrils produced with different $V_{i-\mathrm{BuOH}} \%$ and incubation time, with $c=0.1$ $\mathrm{mg} / \mathrm{mL}$. Scale bars are $500 \mathrm{~nm}$.
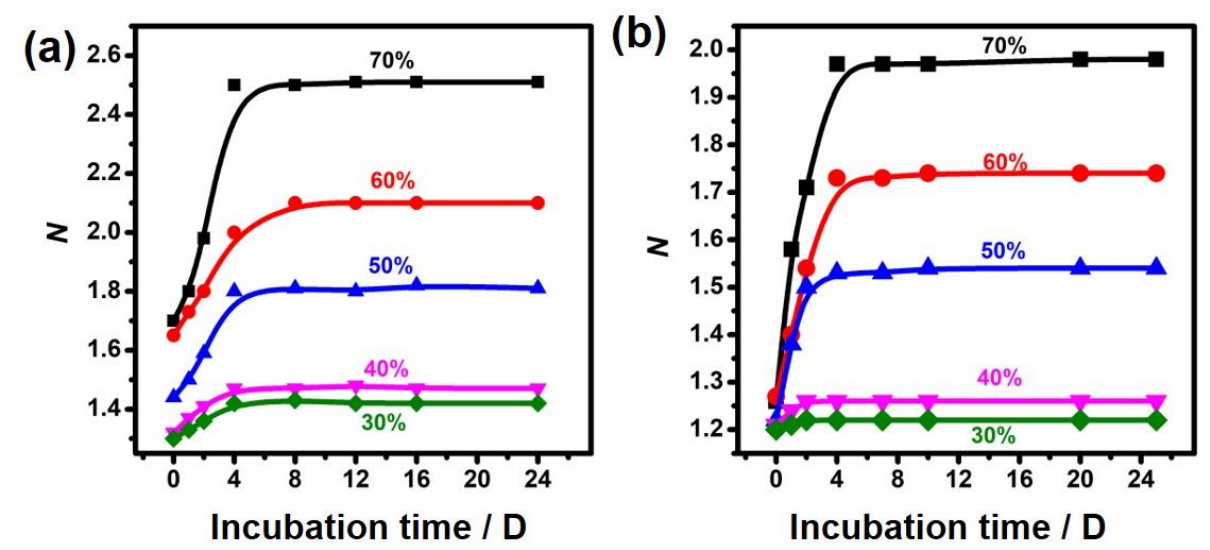

Figure S16 Plots of $N$ versus the incubation time with different $V_{i-\text { BuOH }}$ and concentrations of (a) $0.01 \mathrm{mg} / \mathrm{mL}$, and (b) 0.05 $\mathrm{mg} / \mathrm{mL}$. 


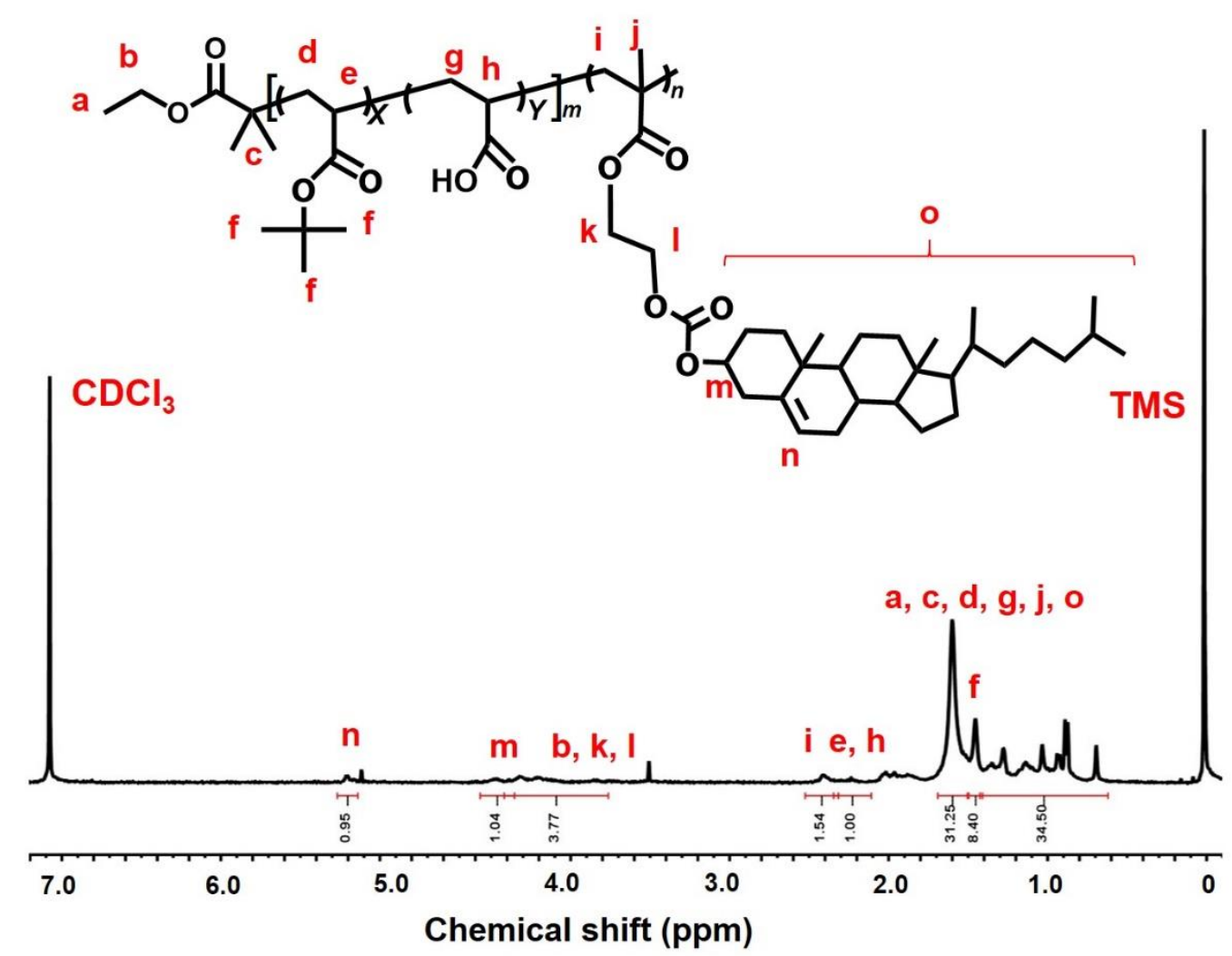

Figure $\mathrm{S1} 7^{1} \mathrm{H}$ NMR spectrum of the $\mathrm{P}(t \mathrm{BA}-r-\mathrm{AA})_{113}-b$-PCholMA 86 diblock copolymer. $\mathrm{CDCl}_{3}$ was used as the solvent.

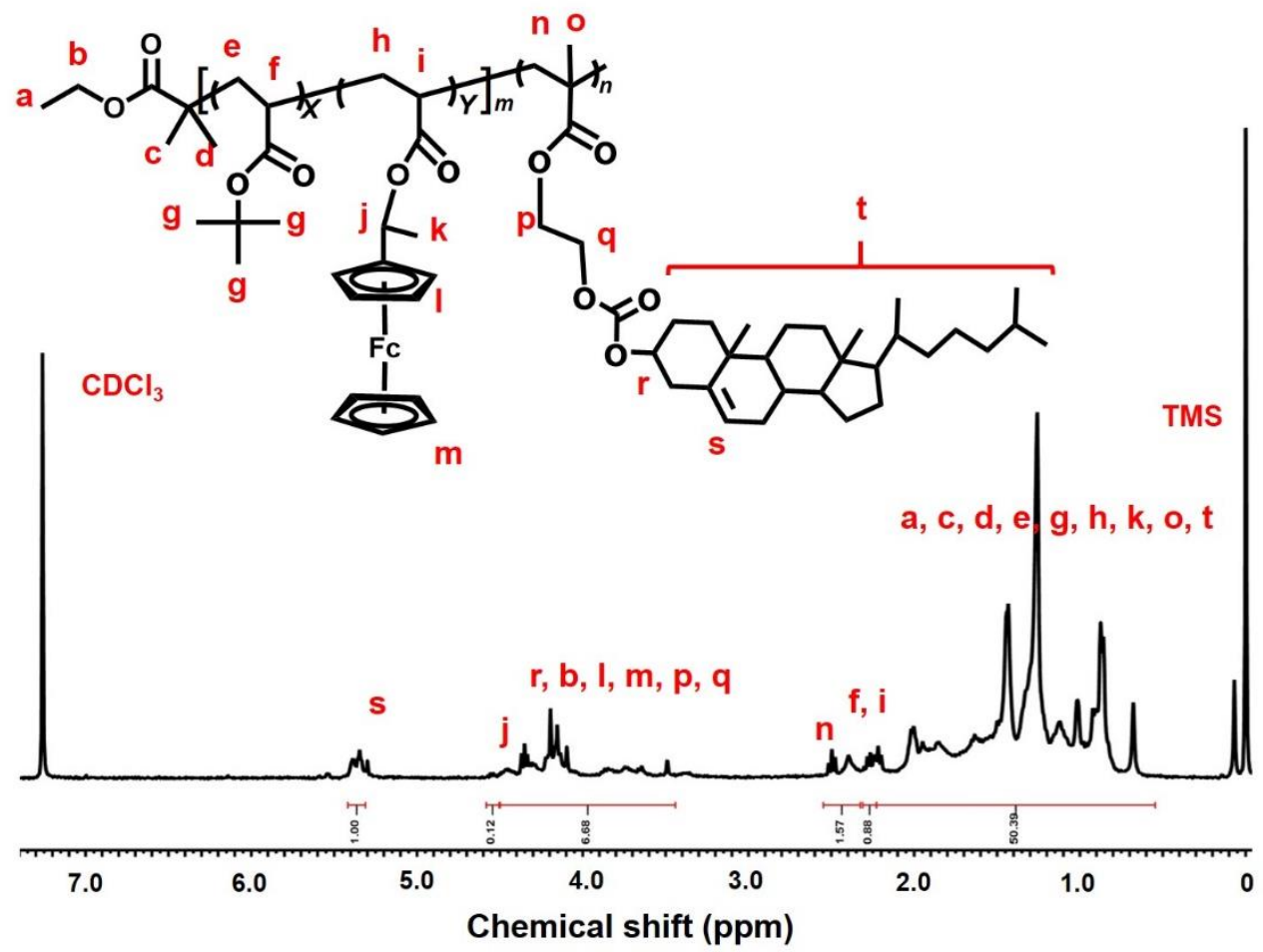

Figure S18 ${ }^{1} \mathrm{H}$ NMR spectrum of the $\mathrm{P}\left(t \mathrm{BA}-r-\mathrm{AA}-\mathrm{F}_{\mathrm{C}}\right)_{113-}-\mathrm{b}-\mathrm{PCholMA}{ }_{86}$ diblock copolymer. $\mathrm{CDCl}_{3}$ was used as the solvent. 

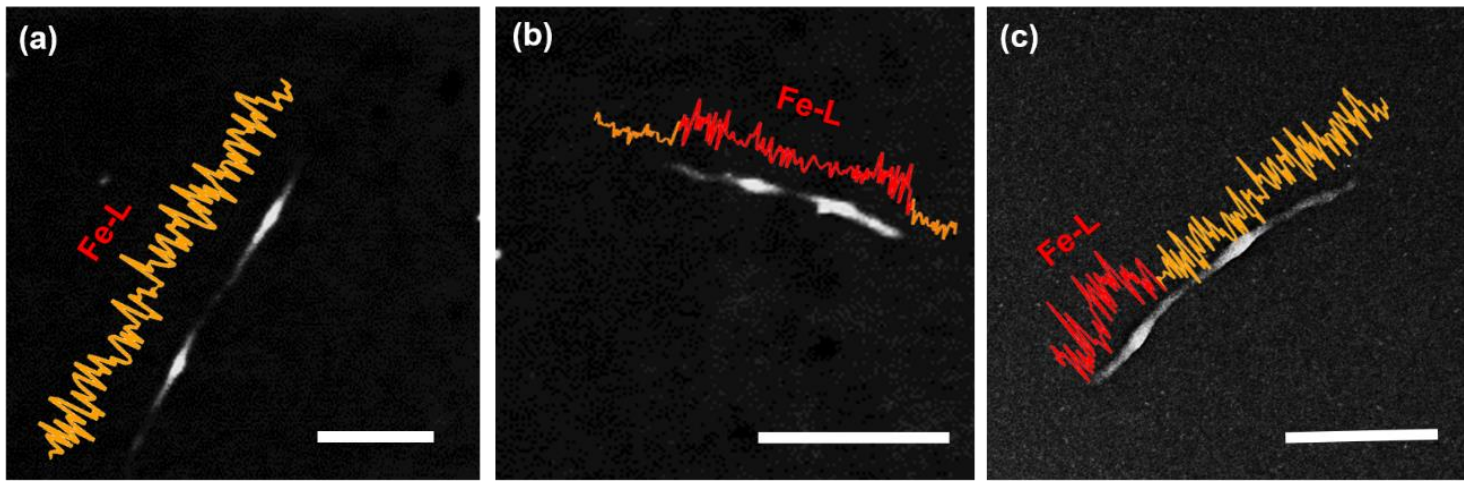

Figure S19 Drak-field TEM images and corresponding EDS analysis of the supramicellar fibrils produced from (a) $623 \mathrm{~nm}$ CM, (b) $321 \mathrm{~nm}-\mathrm{Fc}-\mathrm{CM}$, and (c) a mixture of $623 \mathrm{~nm}-\mathrm{CM}$ and $321 \mathrm{~nm}-\mathrm{Fc}-\mathrm{CM}$. Scale bars are $500 \mathrm{~nm}$. 
Table S1 Molecular characteristics of $\mathrm{P}^{\mathrm{B} \mathrm{BA}_{113}-b-\mathrm{PCholMA}_{86}}$

\begin{tabular}{|c|c|c|c|c|}
\hline$M_{\mathrm{n}}{ }^{a}$ & $M_{\mathrm{w}}{ }^{a}$ & $M_{\mathrm{w}} / M_{\mathrm{n}}{ }^{a}$ & $\mathrm{~m}^{\mathrm{b}}$ & $\mathrm{n}^{\mathrm{c}}$ \\
\hline $61 \mathrm{kDa}$ & $70.2 \mathrm{kDa}$ & 1.15 & 113 & 80 \\
\hline
\end{tabular}

a : obtained from GPC;

$\mathrm{b}$ : degree of polymerization of the first block, calculated by dividing the $M_{\mathrm{n}}$ from GPC results by the molecular weight of monomers;

$\mathrm{c}$ : degree of polymerization of the PCholMA block, calculated from the value of $\mathrm{m}$ and the block ratio from ${ }^{1} \mathrm{H}$ NMR.

Table S2 Length information for monomeric CMs

\begin{tabular}{|c|c|c|c|c|c|}
\hline sample* & $L_{\mathrm{n}}(\mathrm{nm})$ & $L_{\mathrm{w}}(\mathrm{nm})$ & $L_{\mathrm{w}} / L_{\mathrm{n}}$ & $\sigma(\mathrm{nm})$ & $\sigma / L_{\mathrm{n}}$ \\
\hline $30 \%-0.1 \mathrm{mg} / \mathrm{mL}$ & 113 & 114 & 1.02 & 15 & 0.13 \\
\hline $40 \%-0.1 \mathrm{mg} / \mathrm{mL}$ & 174 & 175 & 1.01 & 18 & 0.1 \\
\hline $50 \%-0.1 \mathrm{mg} / \mathrm{mL}$ & 286 & 289 & 1.01 & 27 & 0.09 \\
\hline $60 \%-0.1 \mathrm{mg} / \mathrm{mL}$ & 420 & 426 & 1.01 & 49 & 0.11 \\
\hline $70 \%-0.1 \mathrm{mg} / \mathrm{mL}$ & 321 & 325 & 1.01 & 36 & 0.11 \\
\hline $30 \%-0.05 \mathrm{mg} / \mathrm{mL}$ & 189 & 190 & 1.01 & 15 & 0.08 \\
\hline $40 \%-0.05 \mathrm{mg} / \mathrm{mL}$ & 292 & 294 & 1.01 & 24 & 0.08 \\
\hline $50 \%-0.05 \mathrm{mg} / \mathrm{mL}$ & 557 & 564 & 1.01 & 63 & 0.1 \\
\hline $60 \%-0.05 \mathrm{mg} / \mathrm{mL}$ & 613 & 623 & 1.02 & 79 & 0.13 \\
\hline $70 \%-0.05 \mathrm{mg} / \mathrm{mL}$ & 505 & 510 & 1.01 & 53 & 0.1 \\
\hline $30 \%-0.01 \mathrm{mg} / \mathrm{mL}$ & 382 & 386 & 1.01 & 37 & 0.09 \\
\hline $40 \%-0.01 \mathrm{mg} / \mathrm{mL}$ & 508 & 514 & 1.01 & 59 & 0.12 \\
\hline $50 \%-0.01 \mathrm{mg} / \mathrm{mL}$ & 530 & 633 & 1.01 & 55 & 0.1 \\
\hline $60 \%-0.01 \mathrm{mg} / \mathrm{mL}$ & 673 & 623 & 1.04 & 136 & 0.2 \\
\hline $70 \%-0.01 \mathrm{mg} / \mathrm{mL}$ & 536 & 1.02 & 72 & 0.12 \\
\hline
\end{tabular}

*: represented by (the $i-\mathrm{BuOH}$ volume fraction of the solvent mixture of $i-\mathrm{BuOH}$ and $\mathrm{NMP}$ )-(polymer concentration). $\sigma:$ represents the standard deviation. 
Table S3 Persistence lengths of supramicellar fibrils produced at different conditions.

\begin{tabular}{|c|c|c|}
\hline sample* & $\lambda_{\mathrm{MSED}}(\mu \mathrm{m})$ & $\sigma(\mu \mathrm{m})$ \\
\hline $30 \%-0.1 \mathrm{mg} / \mathrm{ml}$ & 16.2 & 0.38 \\
\hline $40 \%-0.1 \mathrm{mg} / \mathrm{mL}$ & 11.2 & 0.4 \\
\hline $50 \%-0.1 \mathrm{mg} / \mathrm{mL}$ & 6.8 & 0.36 \\
\hline $60 \%-0.1 \mathrm{mg} / \mathrm{mL}$ & 5.2 & 0.03 \\
\hline $70 \%-0.1 \mathrm{mg} / \mathrm{mL}$ & 6.2 & 0.069 \\
\hline $30 \%-0.05 \mathrm{mg} / \mathrm{mL}$ & 9.74 & 0.05 \\
\hline $40 \%-0.05 \mathrm{mg} / \mathrm{mL}$ & 6.4 & 0.07 \\
\hline $50 \%-0.05 \mathrm{mg} / \mathrm{mL}$ & 4 & 0.024 \\
\hline $60 \%-0.05 \mathrm{mg} / \mathrm{mL}$ & 7.4 & 0.2 \\
\hline $70 \%-0.05 \mathrm{mg} / \mathrm{mL}$ & 4.1 & 0.063 \\
\hline $30 \%-0.01 \mathrm{mg} / \mathrm{mL}$ & 5.3 & 0.12 \\
\hline $40 \%-0.01 \mathrm{mg} / \mathrm{mL}$ & 4.4 & 0.055 \\
\hline $50 \%-0.01 \mathrm{mg} / \mathrm{mL}$ & 3.35 & 0.057 \\
\hline $60 \%-0.01 \mathrm{mg} / \mathrm{mL}$ & 2.5 & 0.04 \\
\hline $70 \%-0.01 \mathrm{mg} / \mathrm{mL}$ & 2.6 & 0.034 \\
\hline
\end{tabular}

*: represented by (the $i-\mathrm{BuOH}$ volume fraction of the solvent mixture)-(polymer concentration). $\sigma:$ represents the standard deviation. 
Table S4. Values of $N$ for supramicellar fibrils produced at different conditions immediately after the solutions were cooled to r.t..

\begin{tabular}{|c|c|c|}
\hline sample* & $N$ & $\sigma$ \\
\hline $30 \%-0.1 \mathrm{mg} / \mathrm{mL}$ & 1.37 & 0.76 \\
\hline $40 \%-0.1 \mathrm{mg} / \mathrm{mL}$ & 1.4 & 0.84 \\
\hline $50 \%-0.1 \mathrm{mg} / \mathrm{mL}$ & 1.45 & 0.91 \\
\hline $60 \%-0.1 \mathrm{mg} / \mathrm{mL}$ & 2.1 & 1.54 \\
\hline $70 \%-0.1 \mathrm{mg} / \mathrm{mL}$ & 2.31 & 1.82 \\
\hline $30 \%-0.05 \mathrm{mg} / \mathrm{mL}$ & 1.3 & 0.78 \\
\hline $40 \%-0.05 \mathrm{mg} / \mathrm{mL}$ & 1.32 & 0.87 \\
\hline $50 \%-0.05 \mathrm{mg} / \mathrm{mL}$ & 1.44 & 0.97 \\
\hline $60 \%-0.05 \mathrm{mg} / \mathrm{mL}$ & 1.65 & 1.13 \\
\hline $70 \%-0.05 \mathrm{mg} / \mathrm{mL}$ & 1.7 & 1.04 \\
\hline $30 \%-0.01 \mathrm{mg} / \mathrm{mL}$ & 1.2 & 0.58 \\
\hline $40 \%-0.01 \mathrm{mg} / \mathrm{mL}$ & 1.21 & 0.63 \\
\hline $50 \%-0.01 \mathrm{mg} / \mathrm{mL}$ & 1.22 & 0.6 \\
\hline $60 \%-0.01 \mathrm{mg} / \mathrm{mL}$ & 1.26 & 0.71 \\
\hline $70 \%-0.01 \mathrm{mg} / \mathrm{mL}$ & 1.27 & 0.73 \\
\hline
\end{tabular}

*: represented by (the $i$-BuOH volume fraction of the solvent mixture)-(polymer concentration).

$\sigma$ : represents the standard deviation.

Table S5. DLS results obtained from the supramicellar solution $\left(V_{\mathrm{i}-\mathrm{BuOH}}=70 \%, c=0.1 \mathrm{mg} / \mathrm{mL}\right)$ during incubation.

\begin{tabular}{|c|c|c|}
\hline Time / D & $D_{\mathrm{h}}$ & PDI \\
\hline 1 & 359 & 0.109 \\
\hline 4 & 552 & 0.208 \\
\hline 8 & 559 & 0.210 \\
\hline 12 & 560 & 0.218 \\
\hline 16 & 611 & 0.190 \\
\hline 25 & 615 & 0.185 \\
\hline
\end{tabular}


Table S6. Values of $N_{\text {final }}$ for supramicellar fibrils produced at different conditions.

\begin{tabular}{|c|c|c|}
\hline sample* & $N_{\text {final }}$ & $\sigma$ \\
\hline $30 \%-0.1 \mathrm{mg} / \mathrm{mL}$ & 1.65 & 1.12 \\
\hline $40 \%-0.1 \mathrm{mg} / \mathrm{mL}$ & 2 & 1.62 \\
\hline $50 \%-0.1 \mathrm{mg} / \mathrm{mL}$ & 2.3 & 1.83 \\
\hline $60 \%-0.1 \mathrm{mg} / \mathrm{mL}$ & 2.9 & 1.84 \\
\hline $70 \%-0.1 \mathrm{mg} / \mathrm{mL}$ & 3.35 & 2.3 \\
\hline $30 \%-0.05 \mathrm{mg} / \mathrm{mL}$ & 1.42 & 0.8 \\
\hline $40 \%-0.05 \mathrm{mg} / \mathrm{mL}$ & 1.5 & 0.9 \\
\hline $50 \%-0.05 \mathrm{mg} / \mathrm{mL}$ & 1.8 & 1.16 \\
\hline $60 \%-0.05 \mathrm{mg} / \mathrm{mL}$ & 2 & 1.12 \\
\hline $70 \%-0.05 \mathrm{mg} / \mathrm{mL}$ & 2.5 & 1.3 \\
\hline $30 \%-0.01 \mathrm{mg} / \mathrm{mL}$ & 1.22 & 0.61 \\
\hline $40 \%-0.01 \mathrm{mg} / \mathrm{mL}$ & 1.26 & 0.66 \\
\hline $50 \%-0.01 \mathrm{mg} / \mathrm{mL}$ & 1.54 & 0.95 \\
\hline $60 \%-0.01 \mathrm{mg} / \mathrm{mL}$ & 1.74 & 1.08 \\
\hline $70 \%-0.01 \mathrm{mg} / \mathrm{mL}$ & 1.98 & 1.13 \\
\hline
\end{tabular}

*: represented by (the $i-\mathrm{BuOH}$ volume fraction of the solvent mixture)-(polymer concentration).

$\sigma$ : represents the standard deviation.

\section{References}

(1) Piñol, R.; Jia, L.; Gubellini, F.; Lévy, D.; Albouy, P.-A.; Keller, P.; Cao, A.; Li, M.-H., Self-Assembly of PEG-b-Liquid Crystal Polymer: The Role of Smectic Order in the Formation of Nanofibers. Macromolecules 2007, 40, 5625-5627.

(2) Usov, I.; Mezzenga, R., FiberApp: An Open-Source Software for Tracking and Analyzing Polymers, Filaments, Biomacromolecules, and Fibrous Objects. Macromolecules 2015, 48, 1269-1280. 